and his domestic animals becomes more remote-the gradual restoration of the original flora and fauna, the re-conquest of pasture by forest, and so on. By the work of successive generations of investigators, it will be possible to follow the truly natural successions and changes occurring within the area, and to study in detail the natural relations between soil, climate, and organisms. The safeguarding from interference by man and beast will also be utilised to study the slow secular changes of land and water. In this unique laboratory, the naturalists of Switzerland will find themselves united in a common work. Maintenance expenses, such as the wages of the four park keepers and the upkeep of roads and huts, as well as the cost of the scientific investigations, are provided by the Schweizerische Bund für Naturschutz, an association which at the present time numbers more than 30,000 members. ${ }^{2}$ Thus the Swiss National Park is a commonwealth in which alpine Nature can recover and develop undisturbed: a refuge, a sanctuary for plant and animal life. It is an island of primeval Nature, unaffected by the devastating waves of human civilisation which break about its shores. During visits to this Nature reserve one cannot fail to be impressed by the grandeur of the scenery and the wealth of plant and animal life. But still deeper is the feeling of patriotic pride that a whole nation is pledged to preserve this fragment of primitive Helvetia, unexploited for purposes of material gain, as a heritage for generations yet unborn. It is a piece of idealism especially valuable in this materialistic world.

${ }^{2}$ The annual membership subscription is 2 francs, life membership 50 francs. Foreign members are welcomed; any one wishing to join is invited to communicate with Dr. St. Brunies, Sekretär des Naturschutzbundes, Basel, Oberalpstrasse ir.

\title{
O bituary.
}

\section{Dr. E. F. BASHFORD, O.B.E.}

$A \mathrm{~N}$ outstanding figure in cancer research has been A removed by the death, from heart failure, of Dr. Ernest Francis Bashford. After a most distinguished medical career at the University of Edinburgh, he pursued laboratory investigations in Germany, especially under Ehrlich, and became assistant to Sir Thomas Fraser in pharmacology. Even in the short time he spent in that laboratory, he enriched pharmacology by a memorable contribution on the antagonism of atropine and morphine.

When the organisation now known as the Imperial Cancer Research Fund was started in I902, the committee appointed Bashford as general superintendent and director of the laboratories. So well was the confidence of the committee justified that in a few years his researches were known all over the world, and the laboratory, housed originally in the upper floors of the College of Surgeons' hall on Victoria Embankment, was recognised by all as the leading institute in the world for the experimental study of cancer. The position achieved was the outcome of intense work by a brilliant staff of colleagues inspired and directed by a forceful, imaginative, and tireless personality. The memorandum of proposed research submitted to the committee by Bashford at the commencement is still on record and demonstrates how surprisingly he, a young man with little previous acquaintance with the problems and quite inexperienced in the responsibilities of an institute, had grasped the essential fact that cancer must be studied as a problem in comparative biology. The exact statistical investigations of cancer in human beings in Great Britain and the collection of reports of its occurrence in civilised and uncivilised races early occupied his attention, and his writings proved convincingly that the incidence of the disease could not be correlated with many of the factors that impressed, and still impress, the imagination of the uninitiated. When there was added to this the study of the zoological distribution of cancer, the insistence on the breadth of the problem became obvious.

The first real advance in the biological study originated from the discovery by Jensen of the transplantability of a mouse carcinoma. The avenues thus opened up were enthusiastically explored, and there followed in rapid succession contributions dealing with the cytology of malignant new growths, the source of their cellular constituents, the specific reactions of the host, the induction of artificial resistance to growths, the study of refractoriness or susceptibility, the demonstration of the essential similarity of malignant neoplasms throughout the animal kingdom, biochemical investigations of great importance, and a host of other observations over the whole field which may be found in the first five Scientific Reports of the Imperial Cancer Research Fund published under Bashford's direction. Ill-health compelled him to resign his appointment in I9I4. During the War he served in the Army in France as a pathologist, and was at the time of his death adviser in pathology to the British Forces on the Rhine. His work marks the beginning of the era of the scientific study of cancer in Great Britain.

\section{ARCHIBALD LEITCH.}

\section{LORD MORLEy, O.M., F.R.S.}

LORD MorLey, whose death on September 23, at eighty-four years of age, we regret to record, was a great statesman and intellectual leader, the memory of whose work and noble character will long be cherished. As a writer on literary, historical, and biographical subjects, he covered a wide field in a style at once delightful and stimulating, and in the field of public life he preserved the best traditions of sincerity and truth. Though Lord Morley was not directly concerned with scientific research, he was sympathetic towards it, and was elected a fellow of the Royal Society in $\mathrm{r} 892$ under the rule which permits the Council to nominate for election persons who " either have rendered conspicuous service to the cause of science, or are such that their election would be of signal benefit to the Society." He was a trustee of the British Museum, I894-I92 I, chancellor of the University of Manchester from I908 until last March, and one of the first members of the Order of Merit created by King Edward VII. in I902. Lord Morley was made an honorary LL.D. of the Universities of Glasgow, r879, Cambridge, r892, St. Andrews, r902, and Edinburgh, 1904, and an honorary D.C.L. of Oxford in $\mathrm{x} 896$.

NO. 28 I 3 , VOL. I I 2$]$ 